\title{
SLA Education Division: the Future
}

\author{
By JoAn S. Segal
}

\section{Introduction}

The problem when we think about the future is that it is the supreme unknown. This leads to a tendency to wonder what the future will bring, but to conclude that what will be, will be, and that we will simply take what comes and adapt as best we can.

At the other extreme mare those who blithely predict what will happen. We are drowning in predictions about the future of libraries - from dire warnings that this is a dying profession to glowing visions of a new information society with librarians at its head.

My reaction to this is that the future is inevitable, and that the prediction that will come true is the one that is based on what we do today to make it happen. In other words, we can shape the future now. And one way to do that is through a planning process. I suggest that the SLA Education Division could profit from such a process and that this process is the way to shape the future of the division.

\section{Planning}

Planning begins with a commitment to the process. The Special Libraries

Association has been involved in planning for several years and its model can provide an illustration of how the Educational Division can create its own future as a division and as a part of the whole association.

\section{Present Situation}

A key place to begin the planning process is to consider the present situation of the division. What elements in the environment are having an impact on the division and its members? What is happening that affects the needs of the members and thus the services the division should be providing to them? For instance, externally, education is under fire-in recessionary times, cuts in education budgets are de rigeur and libraries as suffering the trickle-down effect of these cuts. The division is also an integral part of SLA and must be familiar with what is happening there that can be helpful or that needs watching or agitating about.

\section{Analysis}

A process referred to as WOTS-UP is often used to analyze the situation. This stands for Weaknesses, Opportunities, Threats, and Strengths Underlying Planning. The acronym helps remind the planners of the aspects that need to be considered. What are the organization's weaknesses and strengths - these are internal considerations. What are the opportunities and threats from the outside? (Often planners find that threats can be turned into opportunities; that weaknesses addressed can become strengths). For the Education Division, for example, small size and budget might be considered weaknesses, but on the other hand the strengths of the division are common interests and fellowship, which is felt most strongly because of the division's small size. Threats are competition from other divisions of SLA, from chapter activities, and from other associations, but there are opportunities for cooperative activities with these others and to learn from them how to be more effective.

\section{Member Needs}

Members can't tell you what they'd like you to do for them. They can only tell you what is important to them, what are their problems and interests. Then the division can dream up a way to address these problems and interests. Perhaps a focus group of education librarians, both members and non-members, could identify a few of these; or random calls by officers could effectively begin the 
process of finding out what the division can do to serve education librarians.

\section{Missions-Goals - Objectives}

Out of the work on scanning the environment, analyzing the situation, and finding out about member needs, the division can derive a mission statement (in fact, it already has one, as listed in the directory) and a set of goals and objectives that tell how the mission will be accomplished.

\section{Planning Process}

Having done all this work, the division will have a plan, but even more important, it has begun to look at the future from a planning perspective. The process of thinking in these terms must continue, with an ongoing scanning of the environment, a constant effort to determine members' needs, and a regular revision of the goals and objectives.

\section{Conclusion}

But one of the greatest strengths of the Education Division is and probably always will be the fellowship among the members and this matches extremely well with one of the greatest member needs, which is the sharing of ideas. A good start toward the future would be just building on these two elements, turning threats into opportunities, and weaknesses into strengths.

I hope the division will not just let the future come to them, but will create the future desired through a process of planning for it.

JoAn S. Segal is a Past Chair of the Education Division and Associate Director of the American Library Association 


\section{Chairs from the Beginning}

\begin{tabular}{|c|c|c|}
\hline Dates & Name & Institution \\
\hline 2014 & Maya Kucij & McGill University \\
\hline 2013 & Dr. Lesley S. Farmer & California State University, Long Beach \\
\hline 2012 & Bernadette Bailey & American Federation of Teachers \\
\hline 2011 & Debbie Bogenschutz & Cincinnati State Technical and Community College \\
\hline 2010 & Erin Lanham & Covidien Pharma InfoCenter \\
\hline 2009 & $\begin{array}{l}\text { Michelle Bagley } \\
\text { Deborah Garson }\end{array}$ & $\begin{array}{l}\text { Clark College } \\
\text { Harvard University }\end{array}$ \\
\hline 2008 & Dr. Lesley S. Farmer & California State University, Long Beach \\
\hline 2007 & Sharon Weiner & University of Massachusetts Dartmouth \\
\hline $2005-2006$ & Susan Couch & Library National Board of Medical Examiners \\
\hline $2004-2005$ & Dr. Patricia O'Brien Libutti & Rutgers University \\
\hline $2003-2004$ & $\begin{array}{l}\text { Carole Sund } \\
\text { Sheila McGarr }\end{array}$ & $\begin{array}{l}\text { National Education Association } \\
\text { National Library of Education }\end{array}$ \\
\hline $2002-2003$ & Deborah Garson & Harvard University \\
\hline $2001-2002$ & Martha Wilding & Iowa Testing Programs \\
\hline $2000-2001$ & John D'Amicantonio & California State University, Long Beach \\
\hline $1999-2000$ & Jacqueline Snider & ACT \\
\hline 1998-99 & Karen L. McQuillen & Educational Testing Service \\
\hline $1997-98$ & Debbie Bogenschutz & Cincinnati State Technical and Community College \\
\hline 1996-97 & $\begin{array}{l}\text { Juana Alers-Quinones } \\
\text { Kamla Mohitar }\end{array}$ & $\begin{array}{l}\text { Girl Scouts of America } \\
\text { A. Mellon Foundation }\end{array}$ \\
\hline $1995-96$ & John D'Amicantonio & California State University, Long Beach \\
\hline $1994-95$ & Mary Vass & University of Kentucky \\
\hline $1993-94$ & Gladys Dratch & Harvard University \\
\hline $1992-93$ & Maxine Goldsmith & New Jersey Dept. of Higher Education \\
\hline $1991-92$ & Judith Lindley & \\
\hline $1990-91$ & Diane Childs & UCLA \\
\hline $1989-90$ & Charles Missar & Consultant, Washington, D. C \\
\hline $1988-89$ & Hope Tillman & Rider College \\
\hline $1987-88$ & Mary Sue Stephenson & B. C. School of Library, Information an Archival Studies \\
\hline $1986-87$ & Anne Galler & Concordia University \\
\hline $1985-86$ & Suzanne Brown & University of Florida \\
\hline $1984-85$ & Janet Williams & Educational Testing Service \\
\hline $1983-84$ & Susan Baughman & Harvard University \\
\hline $1982-83$ & Suzanne Shackleton & Illinois Office of Education \\
\hline $1981-82$ & JoAn Segal & Bibliographic Center for Research, Denver \\
\hline $1980-81$ & Charles Missar & National Institute of Education Library \\
\hline $1979-80$ & Pauline Rothstein & ERIC Clearinghouse of Urban Education \\
\hline $1978-79$ & Ethel Auster & Ontario Institute for Studies in Education \\
\hline $1977-78$ & Pat Tupper & Minnesota Department of Education \\
\hline 1976-77 & Rosetta P. Martin & Tufts University \\
\hline $1975-76$ & Malcolm Hamilton & Harvard Graduate School of Education \\
\hline $1974-75$ & Priscilla Linsley & Educational Testing Service, Garden State School District \\
\hline 1973-74 & Guest Perry & Houghton Mifflin Co. \\
\hline
\end{tabular}




\section{Education Libraries}

\section{Milestones:}

- $\quad 1975$ Fall-June 1977. Bulletin Education Libraries. First issue. Editor: Guest Perry

- 1977 Fall. New name: Education Libraries, first theme, "Back to Basics"

- 1978 Fall. New look.

- 1979 Winter. First guest editor, Dexter Fox.

- 1988 Winter. Question of peer review raised

- 1991 Winter. Anne Galler became editor

- 1991 Winter. $15^{\text {th }}$ anniversary issue; JoAn Segal's article on the future of the Division

- 1992 Spring. New look

- 1992 Summer. Editorial Board announced

- 1992 Fall/Winter. Article by John U. Ogbu

- 1993 Spring. First refereed issue

- 2005 Summer. Last print issue

- 2005 Winter. First online issue available

- 2013 Spring. Journal added to the Directory of Open Access Journals

\section{Editors:}

- 1975. Guest Perry, Houghton Mifflin

- 1976-1980. Guest Perry, Houghton Mifflin; and Malcolm Hamilton, Gutman Library, Harvard Graduate School of Education, Co-Editors

- 1981-1985. Susan Baughman, Gutman Library, Harvard University

- 1986-1988. Hope Tillman, Rider College Library

- 1989. Lucie M. Olson, Socorro Public Library

- 1990. Hope Tillman, Tufts University, Guest editor

- 1991-1999. Anne Galler, Concordia University

- 1999-2000. Joanne Locke, Concordia University, and Noreen B. Blake, Bake \& Associates, Acting Co-Editors

- 2001. M. Suzanne Brown, Education Library, University of Florida, Guest Editor; Scott Walter, George B. Brain Education Library, Washington State University, Editor

- 2002. Patricia O’Brien Libutti, Rutgers University Libraries, Guest Editor; Scott Walter, Editor

- 2003-2007. Lesley S. J. Farmer, California State University, Long Beach

- 2008-2010. Jacqueline Snider, ACT, and Cybèle Elaine Werts, Co-Editors

- 2010-2014. Jacqueline Snider, ACT 